DOI https://doi.org/10.30525/978-9934-26-075-9-40

\title{
РОСЛИНИ РОДУ РУТВИЦЯ (THALICTRUM) У МЕДИЧНІЙ ТА ФАРМАЦЕВТИЧНІЙ ПРАКТИЦІ
}

\author{
Журавель У. П. \\ студентка кафедри технології біологічно активних сполук, \\ фармаиії та біотехнології \\ Національний університет «Львівська політехніка»
}

Конечна P. T.

кандидат фармацевтичних наук, дочент кафедри технології біологічно активних сполук, фармаиії та біотехнологіі

Національний університет «Львівська політехніка»

Кричковська А. М.

кандидат фармачевтичних наук, доцент кафедри технології біологічно активних сполук, фармаиії та біотехнологіі Національний університет «Львівська політехніка»

Половкович С. В.

доктор хімічних наук, дочент кафедри технології біологічно активних сполук, фармачії та біотехнології

Національний університет «Львівська політехніка»

\section{Губрій 3. В.}

кандидат хімічних наук, доцент кафедри технології біологічно активних сполук, фармачії та біотехнології Національний університет «Львівська політехніка» м. Львів, Україна

Актуальність. Для сучасної фармації та медицини актуальним завданням $є$ розробка та впровадження в практику нових препаратів, які створені на основі лікарської рослинної сировини. Саме лікарські засоби рослинного походження характеризуються збалансованим комплексом 
біологічно активних речовин (БАР), широким спектром дії та потужним потенціалом для використання сучасною фітотерапією. Ще в сиву давнину люди помітили, що багато рослин мають цілющі властивості і почали застосовувати їх для лікування різних захворювань. Одними із таких перспективних представників української флори вважаються рослини роду Рутвиця (Thalictrum), а саме рутвиця орликолиста (Thalictrum aquilegifolium L.), рутвиця смердюча (Thalictrum foetidum), рутвиця та рутвиця мала (Thalictrum minus $L$.).

Мета роботи. Дослідити сучасний стан використання рослин роду Рутвиця у медицині та фармацевтичній практиці та встановити перспективи використання їх при розробці лікарських засобів.

Результати дослідження та їх обговорення. Рутвиця орликолиста (Thalictrum aquilegifolium) належить до родини жовтецеві (Ranunculaceae). Вона має ще й місцеві назви, а саме рутка дика, рутвиця широколиста, м'ята чортова. Типовим ареалом поширення рослини на території України є Карпати, Полісся та Лісостеп.

Рутвиця орликолиста багаторічна трав'яниста рослина, без опушення. Стебло прямостояче заввишки 50-100 сантиметрів, яке галузиться. Листкорозміщення рослини чергове, листки розміщуються на довгих жолобчастих черешках, листкова пластинка двічі або тричіпериста, форма округло-оберненояйцевидна або оберненояйцевидна, спереду листки зарубчасто-лопатеві короткочерешкові або сидячі, завдовжки 2-5 сантиметрів. Квіти рутвиці орликолистої дрібні, зібрані у щитковидні волоті, правильні (актиноморфні), розміщені на ніжках. Оцвітина проста, чашечковидна, листочки оцвітини мають біле, блідно-лілове або зеленувате забарвлення. Цвіте зазвичай з травня по червень. Плоди багатогорішки, які складаються 3 однонасінних горішків і дозрівають вони в липні-серпні [1].

Як лікарську рослинну сировину заготовляють траву рутвиці (Herba Thalictri aquilegifolii), зрізуючи під час цвітіння рослини верхівки стебел завдовжки 30-35 см. Штучне сушіння слід проводити при температурі $40^{\circ} \mathrm{C}$.

Трава Thalictrum aquilegifolium багата на вміст алкалоїдів (близько 0,3\%) - тальмідин, ізокоридин, магнофлорин, берберин. Також рутвиця орликолиста містить ціаногенні сполуки - лінамарин, n-глюкозилгідроксиманделонітрил, $\quad \beta$-глюкозид $\mathrm{n}$-глюкозилгідроксиманделонітрилу, кумарин, фенол-карбонові кислоти (ферулова, кавова та ін.), флавоноїди (кверцетин, кемпферол, лютеолін, апігенін), проте вміст сполук ще не достатньо вивчено [2].

Рутвиця орликолиста широко використовується у медицині, оскільки має антибактеріальні, протизапальні, кровоспинні, болетамуючі й 
сечогінні властивості. У етномедицині застосовують при жовтяниці, проносах, водянці, епілепсії, маткових кровотечах, малярії, туберкульозі легень, дерматозах і ревматизмі. Свіже товчене листя рутвиці застосовують для лікування запрілостей між пальцями ніг, гнійних ран i шкірних захворювань. Трава рутвиці орликолистої входить до складу мікстури Здренка. [2, 3, 4, с. 389].

Рутвиця мала (Thalictrum minus) морфологічно схожа до Thalictrum aquilegifoliu, проте хімічний склад дещо інший. Вона містить не лише алкалоїди, флавоноїди, а також сапоніни $(3,1 \%)$, ціаногенні сполуки, дубильні речовини, вищі аліфатичні вуглеводні та аскорбінову кислоту. Рутвиця мала $\epsilon$ досить відомою у медицині. Вона проявляє болетамувальні, сечогінні, відхаркувальні, седативні, гіпотензивні, кровоспинні, протизапальні й антисептичні властивості. Застосовують при туберкульозі легень та інших захворюваннях органів дихання, простудних захворюваннях (як жарознижуючий засіб), при захворюваннях травного каналу, при набряках різного походження, при затримці сечовиділення i при нирковокам'яній хворобі. В гомеопатії рослину застосовують при гінекологічних та офтальмологічних захворюваннях $[4$, с. $388,5,6]$.

Не менш відомою та затребуваною рослиною являється ще один представник роду Рутвиця - рутвиця смердюча (Thalictrum foetidum). За морфологічним описом вона $є$ схожою до попередніх рослин. Цей вид реліктовий і занесений у Червону книгу України. Назва рутвиці смердючої з'явилася завдяки своєму залозистому опушенню, оскільки виділення 3 нього проявляють для неї своєрідний запах [6]. Заготовляють надземну частину рослини у червні - липні під час цвітіння. У траві Thalictrum foetidum рутвиці смердючої містяться кумарини, сапоніни, алкалоїди (більше ніж 6\%), флавоноїди (понад 1\%), органічні кислоти, дубильні речовини (5,4\%), серцеві глікозиди, близько 98 мг $/ \%$ аскорбінової кислоти. Особливістю рутвиці смердючої $є$ те, що свіжа рослина містить сліди ефірної олії, до складу якої входить камфора. У листі та коренях рослини також знайдені алкалоїди, але в меншій кількості [4, с. $389,6,7]$.

Рутвиця смердюча відіграє значну роль у лікуванні різних захворювань. Її застосовують в науковій медицині у вигляді настойки трави як засіб, що вживають при лікуванні початкових стадій гіпертонічної хвороби, стенокардії та при порушенні кровообігу. Настойка не токсична.

Thalictrum foetidum застосовують і в народній медицині як протизапальний, кровоспинний, седативний, бактерицидний, сечогінний та протиблювотний засіб. Настій трави приймають усередину при неврозах i судомних станах, перенапруженні, розладах травлення i проносах, 
а також захворюваннях печінки і жовчного міхура, набряках і водянці та при внутрішніх і зовнішніх кровотечах. Настій з трави застосовують і як зовнішній засіб для обмивання ран, виразок, гноячкових висипів тощо. Сік, який виділяється коренем даної рослини є хорошим засобом для лікування ран. 3 надземної частини та коренів рослини готують настої та відвари, якими лікують саркому та інші злоякісні новоутворення [4, с. $389,6,7,8]$.

Висновки та перспективи. Рослини роду рутвиця $є$ багатими на біологічно активні речовини. Лікарська рослинна сировина рослин $\epsilon$ перспективною для фітохімічних та фармакологічних досліджень 3 подальшим використання iï у створенні нейрогенних лікарських засобів, що є актуальним для медицини та фармації.

\section{Література:}

1. Рутвиця орликолиста - отруйність та лікувальні властивості. URL: https://info-z.online/index.php/otrujni-roslini/rodyna-zhovtetsevi/632rutvytsia-orlykolysta-otruinist-ta-likuvalni-vlastyvosti (дата звернення: 14.04.2021).

2. Рутвиця орликолиста. URL: https://www.pen.com.ua/herb-rutvytsyaorlykolysta.html (дата звернення: 14.04.2021).

3. Рутвиця орликолиста. URL: https://uk.wikipedia.org/wiki/\%D0\%A 0\%D1\%83\%D1\%82\%D0\%B2\%D0\%B8\%D1\%86\%D1\%8F_\%D0\%BE\%D1 $\% 80 \% \mathrm{D} 0 \% \mathrm{BB} \% \mathrm{D} 0 \% \mathrm{~B} 8 \% \mathrm{D} 0 \% \mathrm{BA} \% \mathrm{D} 0 \% \mathrm{BE} \% \mathrm{D} 0 \% \mathrm{BB} \% \mathrm{D} 0 \% \mathrm{~B} 8 \% \mathrm{D} 1 \% 81$ $\% \mathrm{D} 1 \% 82 \% \mathrm{D} 0 \% \mathrm{~B} 0$ (дата звернення: 14.04.2021).

4. Лікарські рослини: Енциклопедичний довідник / Відп. ред. А. М. Гродзінський. К.: Видавництво «Українська Енциклопедія» ім. М. П. Бажана, Український виробничо-комерційний центр «Олімп», 1992. 544 c.

5. Рутвиця мала. URL: https://uk.wikipedia.org/wiki/\%D0\%A0\%D1\% $83 \%$ D1\%82\%D0\%B2\%D0\%B8\%D1\%86\%D1\%8F_\%D0\%BC\%D0\%B0\%D 0\%BB\%D0\%B0 (дата звернення: 18.04.2021).

6. Рутвиця смердюча - лікувальні властивості та отруйність рослини. URL: https://info-z.online/index.php/otrujni-roslini/rodyna-zhovtetsevi/633rutvytsia-smerdiucha-likuvalni-vlastyvosti-ta-otruinist-roslyny (дата звернення: 18.04.2021).

7. Екофлора України / за ред. Я.П. Дідух. К.: Фітосоціоцентр, 2004. T. $2.480 \mathrm{c}$.

8. Taherpour A. Chemical composition of the essential oil of Thalectrum minus L. of Iran Nat Prod Res. 2008. №22(2). P. 97-100. 